\title{
Gas exchange, root hydraulic conductivity, water use efficiency and the growth of Toona ciliata clones and seedlings
}

\author{
Trocas gasosas, condutividade hidráulica das raízes, eficiência do uso da água e \\ crescimento de mudas clonais e seminíferas de Toona ciliata
Taiane Pires de Freitas de Oliveira', Deborah Guerra Barroso" Fábio Afonso Mazzei Moura de Assis Figueiredo ${ }^{\mathrm{III}}$, Thais Chagas Barros ${ }^{\mathrm{IV}}$, Gregory A. Gambettav ${ }^{\mathrm{v}}$, Eliemar Campostrini ${ }^{\mathrm{VI}}$

\begin{abstract}
Forest plantations established with seedlings have heterogeneity and are difficult to manage, so an alternative is the use of clones with high productivity. In addition, clonal plants differ in the structure of the root system that can influence the water and nutrient uptake efficiency and therefore productivity. We evaluated leaf gas exchange, root hydraulic conductivity, and water use efficiency of Toona ciliata clonal cuttings and the seedlings growth. The study was performed in a completely randomized design with four treatments: a) TC3 clone; b) TC9 clone; c) TC15 clone and d) seedlings with five replicates and ten plants per plot. On the $120^{\text {th }}$ day, the net photosynthetic rate, transpiration and stomatal conductance were evaluated between 12:00 and 13:00 hours and the values calculated as efficient, instantaneous $(\mathrm{A} / E)$ and intrinsic $(\mathrm{A} / \mathrm{gs})$ water use were calculated. Hydraulic root conductivity $\left(k_{\text {rooo }}\right)$ was obtained by applying increasing pressures $(0.1,0.2,0.3$, and $0.4 \mathrm{MPa})$ using Scholander chamber. The height, stem diameter, leaf area, dry mass of shoot and root, length, diameter, surface area and root volume were also determined. The data were submitted to Pearson's correlation and analysis of variance, comparing by Tukey's test $(5 \%)$. The genetic materials studied presented an equal capacity of water absorption and transport by the roots, even though they exhibited a visual anatomical differences of the root system. Although, the clones exhibited low transpiration and net photosynthetic rates, they were generally more efficient in water use, and the TC 3 and TC9 clones were more efficient to convert the assimilated carbon to biomass.
\end{abstract}

Keywords: Photosynthesis; Root hydraulic conductivity; Toona ciliata, Cuttings

\section{Resumo}

As plantações florestais estabelecidas com mudas apresentam heterogeneidade e dificuldades de manejo. Assim, uma alternativa a estes obstáculos é o uso de clones com alta produtividade. Além disso, as plantas clonais diferem das plantas seminíferas na estrutura do sistema radicular, o que pode influenciar a eficiência na absorção de água e de nutrientes minerais e, portanto, a produtividade. Nesta pesquisa, avaliaram-se as trocas gasosas foliares, a condutividade hidráulica da raiz, a eficiência no uso da água e o crescimento de plântulas de estacas clonais e de plantas propagadas por semente da espécie Toona ciliata. O estudo foi realizado em delineamento inteiramente casualizado com quatro tratamentos: a) clone TC3; b) clone TC9; c) clone TC15 e d) mudas seminíferas, com cinco repetições e dez plantas por parcela. Aos 120 dias, a taxa fotossintética líquida, a transpiração e a condutância estomática foram avaliadas entre as $12 \mathrm{~h} 00$ e as $13 \mathrm{~h} 00$ horas, e a partir desses valores foram calculados as eficiências instantânea $(A / E)$ e intrínseca $(A /$ $g s)$ do uso da água. A condutividade hidráulica da raiz $\left(K_{\text {roo }}\right)$ foi obtida pela aplicação de pressões crescentes $(0,1,0,2,0,3$ e $0,4 \mathrm{MPa})$ neste órgão por meio de uma câmara de pressão. A altura, o diâmetro do caule, a área foliar, a massa seca da parte aérea e raiz, o comprimento, o diâmetro, a área superficial e o volume radicular foram determinados. Os dados foram submetidos à correlação de Pearson e à análise de variância, comparando-se pelo teste de Tukey (5\%). Os materiais genéticos estudados tiveram igual capacidade de absorção e transporte de água através das raízes, apesar de terem diferenças anatômicas visuais do sistema radicular. Os clones tiveram taxas de transpiração e taxa fotossintética líquida reduzidas, e estes foram mais eficientes no uso da água. Os clones TC3 e TC9 foram mais eficientes na conversão do carbono assimilado em biomassa.

Palavras-chave: Fotossíntese; Condutividade hidráulica da raiz; Toona ciliata; Mudas

\footnotetext{
Engenheira Florestal, Dr ${ }^{\text {a }}$., Universidade Estadual do Norte Fluminense - Darcy Ribeiro, Av. Alberto Lamego, 2000, CEP 28013-602, Campos dos Goytacazes (RJ), Brasil. ibitaiane@hotmail.com (ORCID: 0000-0002-9041-6127)

Engenheira Agrônoma, Drª ., Professora Associada do Laboratório de Fitotecnia, Universidade Estadual do Norte Fluminense - Darcy Ribeiro, Av. Alberto Lamego, 2000, CEP 28013-602, Campos dos Goytacazes (RJ), Brasil. deborah@uenf.br (ORCID: 0000-0002-6869-8076)

III Engenheiro Agrônomo, Dr., Professor da Universidade Estadual do Maranhão, Cidade Universitária Paulo VI, Av. Lourenço Vieira da Silva, 1000, Bairro Jardim São Cristovão, CEP 65055-310, São Luís (MA), Brasil. figueiredo.uema@gmail.com (ORCID: 0000-0002-6904-9828)

IV Engenheira Florestal, MSc., Doutoranda em Agronomia, Universidade Estadual Paulista "Júlio de Mesquita Filho", Via de Acesso Prof. Paulo Donato Castellane, s/n, CEP 14884-900, Jaboticabal (SP), Brasil. thaisbarross@hotmail.com (ORCID: 0000-0002-4275-0091)

Biólogo, PhD., Professor da Bordeaux Science Agro, Institut des Sciences de la Vigne et du Vin, Ecophysiologie et Génomique Fonctionnelle de la Vigne, UMR 1287, F-33140 Villenave d'Ornon, França. gregory.gambetta@agro-bordeaux.fr (ORCID: 0000-0002-8838-5050)

vı Engenheiro Agrônomo, Dr., Professor Associado do Laboratório de Fisiologia Vegetal, Universidade Estadual do Norte Fluminense - Darcy Ribeiro, Av. Alberto Lamego, 2000, CEP 28013-602, Campos dos Goytacazes (RJ), Brasil. campost@uenf.br (ORCID: 0000-0002-1329-1084)
} 


\section{Introduction}

The success of timber plantations depends on their photosynthetic capacity and the water use efficiency, among other factors, considering the environmental conditions during the plant establishment. Plants can be subjected to different types of stress in these environments, including high light intensity, high temperature, and low water availability. In this context, it is very important to select genotypes which present higher photosynthetic rates and/or lower losses through the respiratory process under these conditions of environmental stress. However, the majority of researchers still use only biometric characteristics to select and to determine seedling qualities, since these characteristics are easy and inexpensive to measure.

For Toona ciliata, which has excellent quality wood and high economic value (PINHEIRO; LANI; COUTO, 2006), the Brazilian plantations are almost entirely planted from the seed. However, due to the difficulties of handling the heterogeneous population and in order to obtain high productivity and fast growing genotypes, the planting of clones has been a viable alternative and is gaining popularity among the producers.

Plant root systems serve numerous functions including mechanic support, water and soil nutrients uptake, nutrients storage and synthesis of growth regulators (FITTER, 1991; GREGORY, 1994). The efficiency of the root system in absorbing water and nutrients strongly affects the growth of the aerial part of the plants (KOZLOWSKI; PALLARDY, 1997). This growth is the result of the difference between the gain of carbon via photosynthesis and the loss via respiration (ATKIN; SCHEURWATER; PONS, 2007). Studies aimed at understanding the root system structure are of fundamental importance to explain the ecophysiological processes related to the tree mineral nutrition and water balance (GONÇALVES; MELO, 2005).

Vegetative propagated clones and plants established from seeds show differences between their root systems. In the plants originated from seeds, the root system is developed from the dominant primary root with ramifications or lateral roots (RAVEN; EICHHOM; EVERT, 2014). On the other hand, the root system formed from the clone seedlings is adventitious and it can be able to be formed from the stem or, in some cases, from the leaves. For Toona ciliata it is still unclear if these differences in the root origin result in differences in the root behavior.

Plant water transport from the soil, into the roots, through stems and leaves, and into the atmosphere is regulated by the hydraulic conductivity $(k)$ of each part involved in the pathway. Therefore, changes that decrease $k$ especially in the early portions of the pathway (e.g. root) will increase the tension in the plant (MAUREL; SIMONNEAU; SUTKA, 2010), possibly decreasing the leaf gas exchange (TYREE; EWERS, 1991; HUBBARD; BOND; RYAN, 1999), resulting in negative effects on growth and productivity.

Numerous factors influence the hydraulic conductivity of the root system $\left(k_{\text {root }}\right)$, such as the anatomic characteristics (number and the diameter) of the xylem vessel (TOMBESI et al., 2010), root surface area (SOLARI; PERNICE; DEJONG, 2006), the confinement and the deformation of the root (FIGUEIREDO et al., 2014a), and abiotic stresses (BOURSIAC et al., 2008).

Differences in $k_{\text {root }}$ could potentially have large effects on the efficiency of the plant water use (WUE). For example, in soybeans, sorghum and millet plants, the capacity in conserving water is related to the transpiration restriction in an environment of high evaporative demand of the air [high values of air vapour pressure deficit $\left(\mathrm{VPD}_{\text {air }}\right)$ ( GHOLIPOOR et al., 2010; KHOLOVA et al., 2010; GILBERT et al., 2011). This capacity of water conservation in the aerial part is related to the low hydraulic conductivity in the plant that reduces the turgor pressure of the cells and promotes stomata closure.

In those genotypes with restricted transpiration rate at high $\mathrm{VPD}_{\text {air }}$, it has been hypothesized (SINCLAIR; ZWIENIECKI; HOLBROOK, 2008) that low hydraulic conductance in the plant limits the flow of water to guard cells so that there is a loss of guard cell turgor and a decrease in stomatal conductance. The decrease in stomatal conductance results in a new balance of lower water flow into, and evaporation rate from, guard cells under higher $\mathrm{VPD}_{\text {air }}$ 
conditions. The source of the limiting hydraulic conductance under high VPD air might be in roots and/or leaves. Sinclair, Zwieniecki and Holbrook (2008) demonstrated that the limiting hydraulic conductance in soybeans genotype was between the leaf xylem and the guard cells. According to Boyer (1985), the root hydraulic resistance to water flow through whole plants is higher than the shoot resistance.

It has been hypothesized that clone seedlings may have higher $k_{\text {root }}$ possibly through larger root volume and quantity of fine roots. This higher $k_{\text {root }}$ would increase gas exchange at midday and positively influence shoot growth and plant productivity. The goal of this study was to evaluate this hypothesis through measures of midday gas exchange, $k_{\text {root }}$, WUE, and the growth of Toona ciliata var. australis, from clonal and seminal seedlings.

\section{Materials and methods}

\section{Cultivation conditions of Toona ciliata}

The study was performed in a greenhouse at the Universidade Estadual do Norte Fluminense- UENF, Campos dos Goytacazes, Rio de Janeiro state (RJ) (21⒋47”'S and 4118'24”W), Brazil. The treatments consisted of either seedlings produced from minicutting plants for clones TC3, TC9 and TC15 and seedlings originated from seed.

The seed used in the experiment was acquired from Caiçara Comércio de Sementes Ltda., located in Brejo Alegre, SP state, derived from the seed production area, located in Venda Nova do Imigrante - ES state, Brazil (2020'23”S and 410' $05^{\circ}$ ”W). Two seeds were put into polyvinyl chloride (PVC) pots of $280 \mathrm{~cm}^{3}$, containing commercial forest substrate made out of decomposed pine tree bark, and were maintained in a greenhouse with plastic coverage (plastic covering film $150 \mu \mathrm{m}$ ) with $30 \%$ photosynthetic photon flux interception. When the plants presented two pairs of leaves, the pots were thinned out, leaving only one plant per pot. On the sowing day, the minicuttings of the three clones (TC3, TC9 and TC15) were prepared with $5 \mathrm{~cm}$ of height, average diameter of $3.6 \mathrm{~mm}$ and a pair of leaves reduced in $50 \%$ to their leaf area. These minicuttings were cultivated in the same PVC pots types of $280 \mathrm{~cm}^{3}$ with the same substrate used to cultivate the seedlings and they remained in a nebulization chamber for thirty days until rooting. After this period, the mini plant cutting completed the production cycle in a greenhouse, with plastic coverage (plastic covering film $150 \mu \mathrm{m}$ ) with $30 \%$ photosynthetic photon flux interception. During the cultivation of the clone plants along with the seedlings in an environment without nebulization, the micrometeorological variables (temperature and relative humidity) of the greenhouse were monitored at each hour using automatic sensors of data collection (Data Logger RHT10 Model) (Extech Instruments, USA), recording in average temperature of $25^{\circ} \mathrm{C}$ and relative humidity of $74.5 \%$. From these variables the $\mathrm{VPD}_{\text {air }}$ was calculated according to the equation proposed by Jones (1992), finding on average $1.1 \mathrm{kPa}$. The micrometeorological variables of the greenhouse during the gas exchange measurements between 12:00 HR and 13:00 HR were $36.6^{\circ} \mathrm{C}, 61 \%$ and $2.4 \mathrm{kPa}$ on average.

On the $120^{\text {th }}$ day, at the end of the seedling and cuttings formation period, the net photosynthetic rate, transpiration, stomatal conductance, instantaneous and intrinsic water use efficiency and the root hydraulic conductivity were evaluated. At this date, height, stem diameter, leaf area, shoot dry mass and root dry mass, length, diameter, area and root volume were also evaluated.

\section{Gas exchange}

The net photosynthetic rate $(A)$, transpiration $(E)$ and stomatal conductance $(g s)$, were determined using the infrared gas analyzer (IRGA), Li-6400 model (Li-Cor, Lincoln, NE, USA). 
A $1500 \mu \mathrm{mol} \mathrm{m} \mathrm{m}^{-2} \mathrm{~s}^{-1}$ light intensity was used on a $6 \mathrm{~cm}^{2}$ leaf surface, using an artificial lighting system composed of a mix of blue and red light-emitting diodes coupled to the equipment. The measurements were performed in a fully expanded leaf, in the third pair, from the apex. These evaluations started as 12:00 and extended until 13:00 HR, in the moment of higher atmospheric demand for water (FIGUEIREDO et al., 2014b). The air temperature $\left({ }^{\circ} \mathrm{C}\right)$, relative humidity (\%) and $\mathrm{VPD}_{\text {air }}(\mathrm{kPa})$ inside the infrared gas analyzer chamber, during the measures were $36.8 \pm 2^{\circ} \mathrm{C}$, $26.1 \pm 2 \%$ and $4.4 \pm 1 \mathrm{kPa}$ for the air temperature, relative humidity and air vapour pressure deficit.

Instantaneous water use efficiency (WUE) and intrinsic water use efficiency (iWUE)

The instantaneous water use efficiency (WUE) was obtained by the relation between the net photosynthetic rate and the transpiration $(A / E)$ and the intrinsic water use efficiency (iWUE) was obtained by the ratio between the net photosynthetic rate and the stomatal conductance $(A /$ $\left.g_{s}\right)$.

\section{Root hydraulic conductivity $\left(\mathrm{k}_{\text {root }}\right)$}

The hydrostatic root hydraulic conductivity $\left(k_{\text {root }}\right)$ was determined by measuring the steady state flow at four pressures $(0.1 ; 0.2 ; 0.3$; and $0.4 \mathrm{MPa})$. Each plant was removed from the pot and the aerial part of the plant was cut off under water. The whole root system was put in another vessel containing water, and both were immediately inserted into a Scholander chamber (Soil Moisture model, California, USA). Positive pressures were applied at 0.1, 0.2, 0.3, and 0.4 $\mathrm{MPa}$ (proceeding from low to high pressure). At each pressure step the xylem sap in the stem was collected and weighed on a precision analytical balance (TYREE, 2003). Pressure flow curves were constructed and $k_{\text {root }}$ was determined by determining the slope of the linear regression of this relationship (Figures 1 and 2).

\section{Growth measurements}

At 120 days (end of the experiment), the shoot height and the stem diameter of the clones and seedling were measured using a ruler and a digital caliper, respectively. The leaf area was determined using the leaf area meter (model LI-3000, LI-COR Inc, USA). To evaluate the root system, roots were washed with water using sieves to retain the roots. After the washing, the roots were placed in an acrylic tank of $20 \mathrm{~cm}$ of width and $30 \mathrm{~cm}$ of length, containing distilled water, and were analyzed for length, diameter, area and root volume, using the WinRhizo Pro 2007a software (Régent Instr. Tnc.), connected to a professional scanner Epson XL 10000 with a 400 dpi resolution.

To determine the dry mass, both the shoot and the root system were put, separately, in paper bags, inserted in an oven with forced air circulation at $65^{\circ} \mathrm{C} \pm 2$ for 72 hours, to be weighed in an analytical balance later.

\section{Experimental study design}

The study was implanted in completely randomized design, with five replications. The data presented a homoscedasticity and normal distribution, verified by the Cochran and Lilliefors tests. After the application of these tests, data were analyzed using Pearson's correlation and analysis of variance and the differences were compared by Tukey's Test (5\%). The water flow quantitative data were submitted to a regression analysis as a function of applied pressure. 


\section{Results and discussion}

Figure 1 shows a typically example of the pressure vs. flow relationship in the root system in Toona ciliata clones and seedlings. The flow increased linearly with the applied pressure linear consistent as described in Knipfer and Steudle (2008) and Knipfer and Fricke (2011).

\section{Figure 1 - Example of a linear pressure flow relationship for a Toona ciliata root system.}

Figura 1 - Exemplo de uma relação de fluxo linear de pressão para o sistema radicular de Toona ciliata.

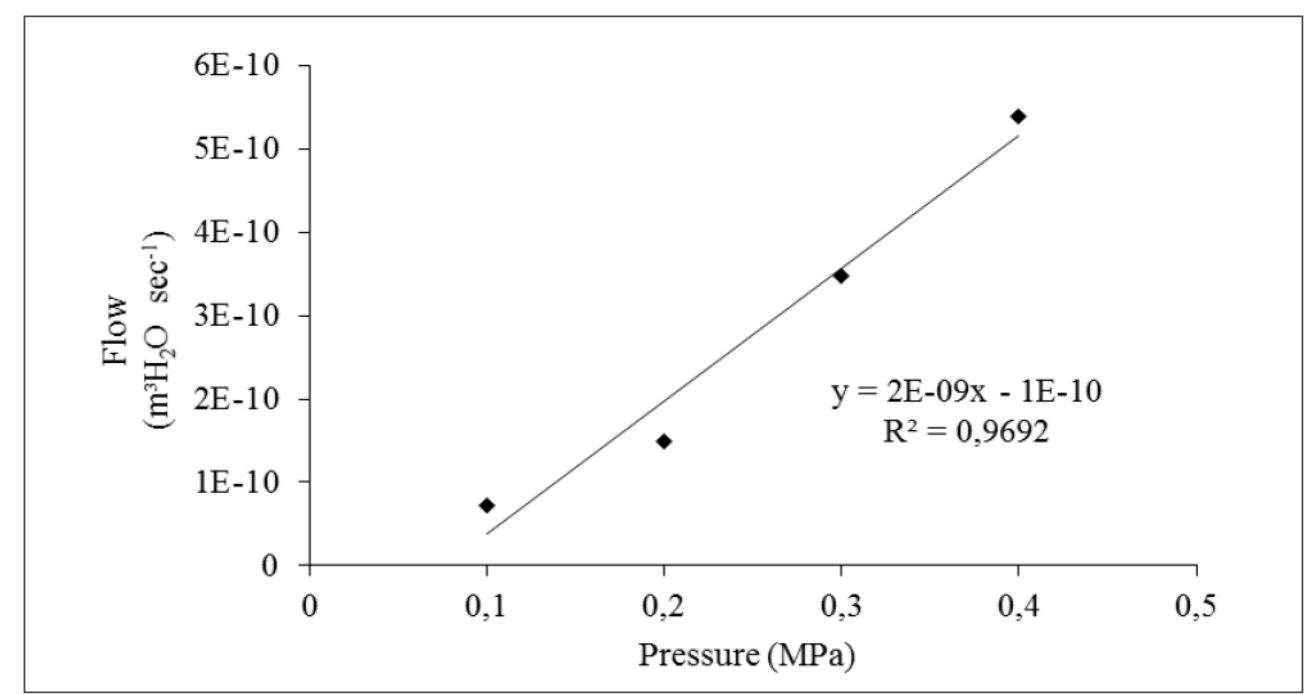

Fonte: Oliveira, T. P. F. (2016)

There was no difference between the clones (TC3, TC9 and TC15) and the seedlings for the hydraulic conductivity of the root $\left(k_{\text {roo }}\right)$ by the dry mass of the root system (Figure 2a), the volume of the root system (Figure 2b), the volume of thin roots $(\varnothing 0-2 \mathrm{~mm})$ (Figure 2c), the root surface area (Figure $2 \mathrm{~d}$ ), thin root surface area $(\varnothing 0-2 \mathrm{~mm})$ (Figure 2e) and non-normalized (Figure 2f).

The water absorption and transport by roots are influenced by several factors, such as the anatomic characteristics of the xylem (TOMBESI et al., 2010), the confinement and the deformation of the roots (FIGUEIREDO et al., 2014a), and the lower number of cells in the cortex (STEUDLE; PETERSON, 1998; RIEGER; LIVTIN, 1999). The evaluation of these variables in future studies with clones of Toona ciliata plants is relevant. Thus, in the Toona ciliata plants it will be important to incorporate measures of $k_{\text {root }}$ in future studies aimed at understanding responses to water deficit and/or high VPD ${ }_{\text {air }}$ since these studies were not found in the literature for T. ciliata.

Seedlings exhibited a higher net photosynthetic rate at when compared to the clones, with an average of $7.04 \mu \mathrm{mol} \mathrm{CO}_{2} \mathrm{~m}^{-2} \mathrm{~s}^{-1}$, and this result was due to a higher stomatal conductance $\left(0.10 \mathrm{~mol} \mathrm{H}_{2} \mathrm{O} \mathrm{m}^{-2} \mathrm{~s}^{-1}\right)$ and transpiration $\left(3.19 \mathrm{mmol} \mathrm{H}_{2} \mathrm{O} \mathrm{m}^{-2} \mathrm{~s}^{-1}\right)$ (Table 1). The direct relationship between the photosynthetic rate and the stomatal conductance was also observed by Murphy, Jordan and Brodribb (2012) in Toona ciliata seedlings, with the highest photosynthetic rate $(9$ $\mu \mathrm{mol} \mathrm{CO} \mathrm{m}^{-2} \mathrm{~s}^{-1}$ ) also showed greater stomatal conductance between 10:00 and 13:00 $\mathrm{HR}$, when cultivated under high irradiation. 
Figure 2 - Root Hydraulic Conductivity, by the dry mass of the root system (a), the volume of the root system $(b)$, the volume of thin roots $(\varnothing 0-2 \mathrm{~mm})(\mathrm{c})$, the root surface area $(\mathrm{d})$, thin root surface area $(\varnothing 0-2 \mathrm{~mm})(e)$ and non-normalized one $(\mathrm{f})$, considering the three clones and seedlings of Toona ciliata at 120 days.

Figura 2 - Condutividade hidráulica das raízes pela massa seca do sistema radicular (a), pelo

volume do sistema radicular (b), pelo volume das raízes finas $(\varnothing 0-2 \mathrm{~mm})(\mathrm{c})$, pela área de superfície das raízes (d), pela área de superfície das raízes finas (Ø 0-2mm) (e) e não normalizada (f), considerando-se os três clones e as mudas propagadas por semente de Toona ciliata aos 120 dias.

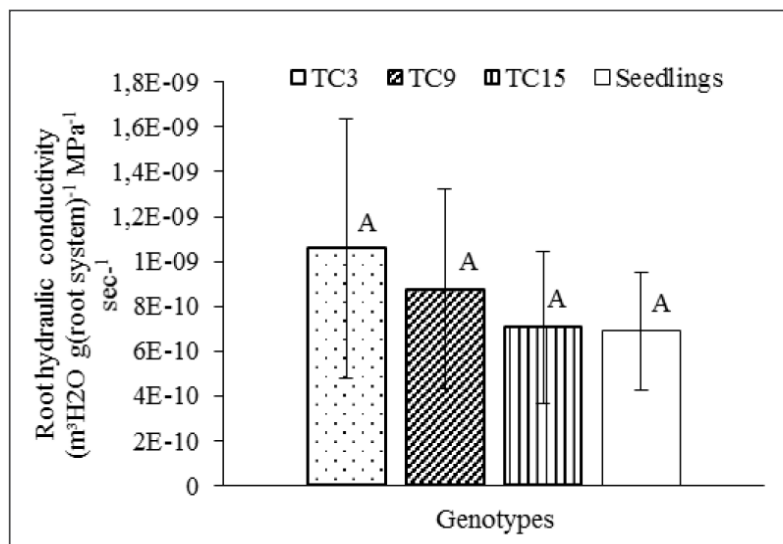

(a)
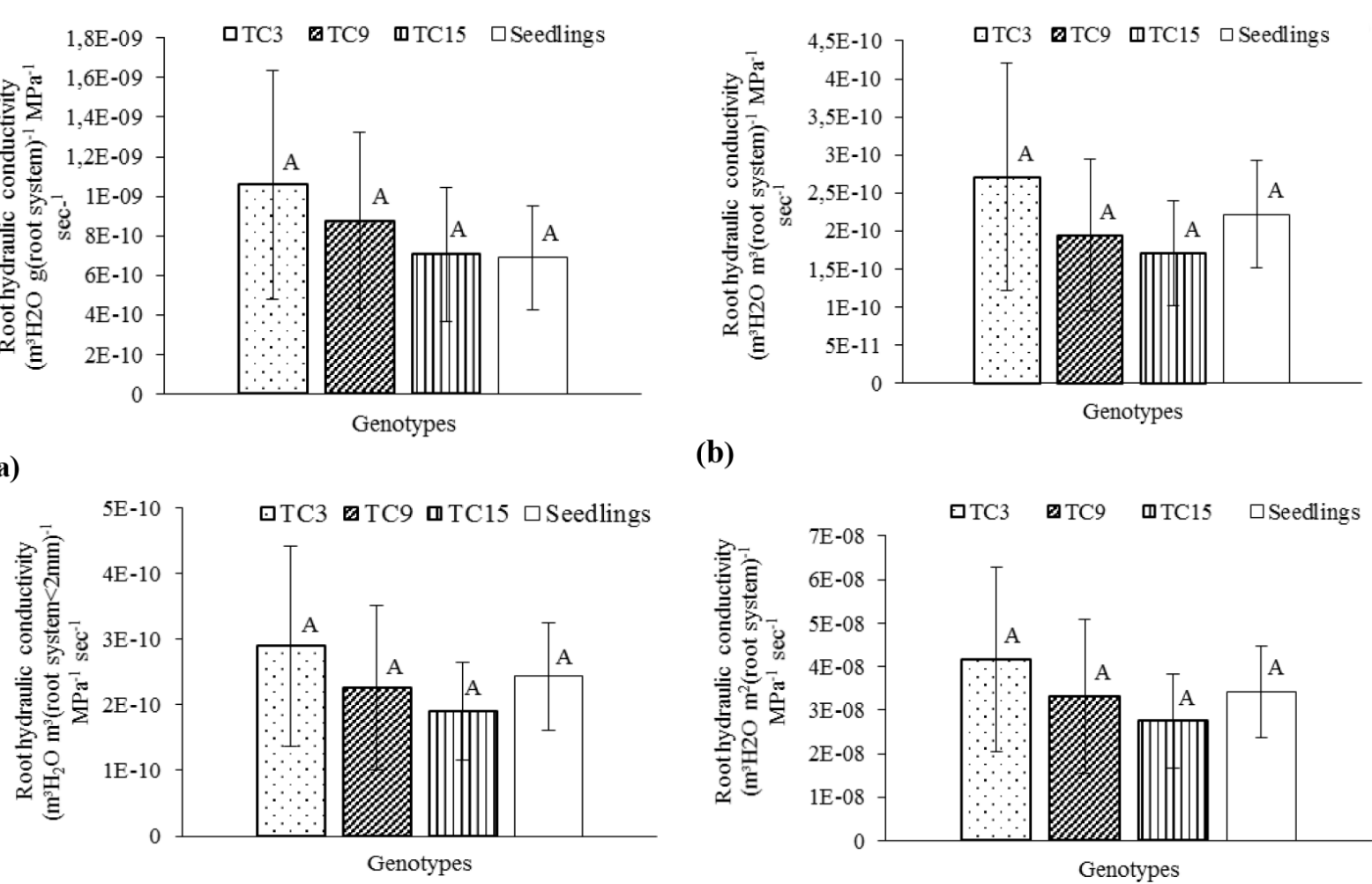

(b)

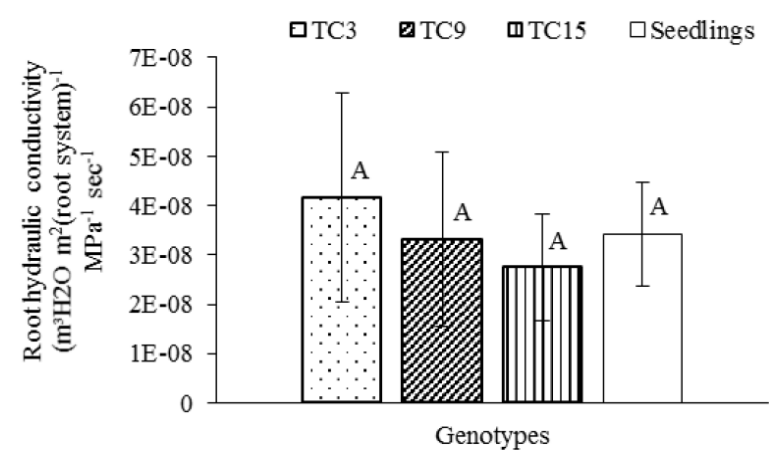

(c)

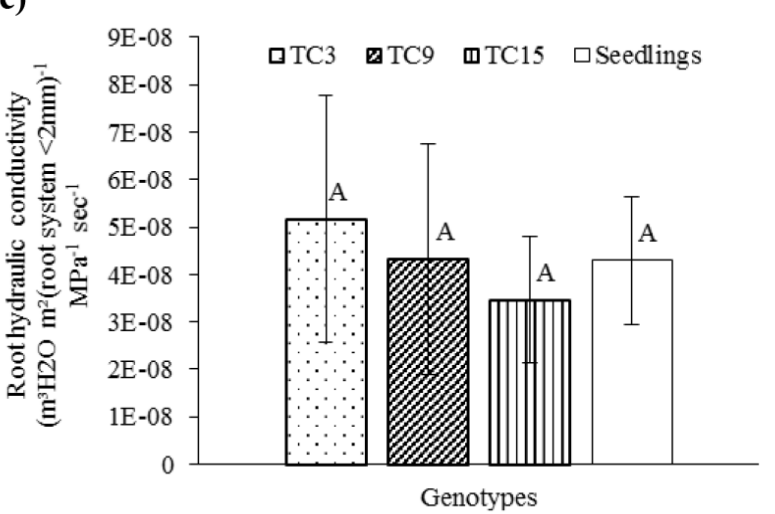

(d)

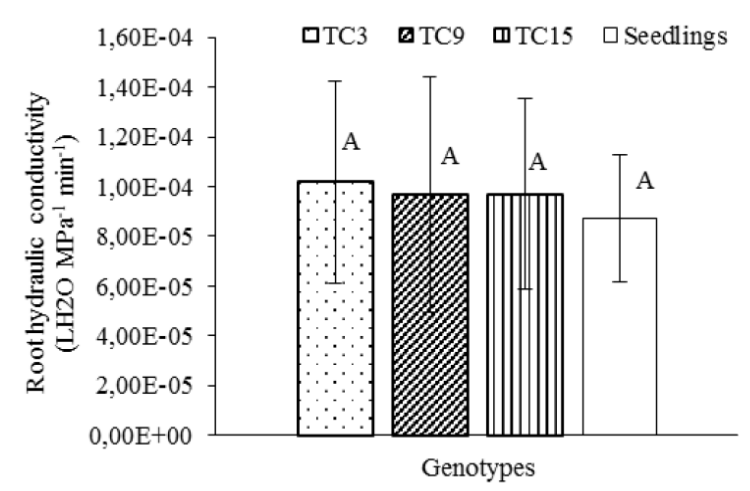

(e)

(f)

Fonte: Oliveira, T. P. F. (2016) 
Table 1 - Net photosynthetic rate $\left(\mu \mathrm{molCO}_{2} \mathrm{~m}^{-2} \mathrm{~s}^{-1}\right)$, Stomatal conductance $\left(\mathrm{mol} \mathrm{H}_{2} \mathrm{O} \mathrm{m}^{-2} \mathrm{~s}^{-1}\right)$ and Transpiration $\left(\mathrm{mmol} \mathrm{H}_{2} \mathrm{O} \mathrm{m}^{-2} \mathrm{~s}^{-1}\right)$ of three clones (TC3, TC9 e TC15) and seedlings Toona ciliata clones at 120 days, measured between 12:00 and 13:00.

Tabela 1 - Taxa fotossintética líquida, condutância estomática e transpiração de três clones (TC3, TC9 e TC15) e mudas propagadas por semente de Toona ciliata aos 120 dias, mensurados entre $12 \mathrm{~h} 00$ e $13 \mathrm{~h} 00$.

\begin{tabular}{|c|c|c|c|c|c|c|c|c|c|c|}
\hline \multirow[t]{2}{*}{ Variables } & \multicolumn{10}{|c|}{ Genotypes } \\
\hline & \multicolumn{2}{|c|}{$\begin{array}{c}\text { TC3 } \\
\text { Clone } \\
\end{array}$} & \multicolumn{2}{|c|}{$\begin{array}{c}\text { TC9 } \\
\text { Clone } \\
\end{array}$} & \multicolumn{2}{|c|}{$\begin{array}{l}\text { TC15 } \\
\text { Clone } \\
\end{array}$} & \multicolumn{2}{|c|}{ Seedlings } & \multirow{2}{*}{$\begin{array}{c}\text { Average } \\
3.95\end{array}$} & \multirow{2}{*}{$\begin{array}{c}\text { CV (\%) } \\
38.6\end{array}$} \\
\hline $\begin{array}{l}\text { Net photosynthetic rate } \\
\left(\mu \mathrm{molCO}_{2} \mathrm{~m}^{-2} \mathrm{~s}^{-1}\right)\end{array}$ & 2.81 & $\mathrm{BC}$ & 1.49 & C & 4.47 & $\mathrm{AB}$ & 7.04 & A & & \\
\hline $\begin{array}{l}\text { Stomatal conductance } \\
\left(\mathrm{mol} \mathrm{H}_{2} \mathrm{O} \mathrm{m}^{-2} \mathrm{~s}^{-1}\right)\end{array}$ & 0.03 & B & 0.01 & B & 0.03 & B & 0.10 & A & 0.04 & 62.0 \\
\hline $\begin{array}{l}\text { Transpiration } \\
\left(\mathrm{mmol} \mathrm{H}_{2} \mathrm{O} \mathrm{m}^{-2} \mathrm{~s}^{-1}\right)\end{array}$ & 1.09 & $\mathrm{BC}$ & 0.50 & C & 1.63 & B & 3.19 & A & 1.60 & 38.5 \\
\hline
\end{tabular}

Averages followed by the same capital letter in the line do not differ among themselves by Tukey's test $\mathrm{P}<0.05$.

In the present study, it is not possible to establish a relationship between the gas exchange responses and the hydraulic conductivity of the roots, since there was no statistical difference between the genetic materials (Figure 2). In fact, $\mathrm{k}_{\text {root }}$ was not correlated with values of the gas exchange across genotypes (Table 3 ). This response can demonstrate that the $k_{\text {root }}$ component may not significantly impact stomatal conductance under these conditions. The leaf hydraulic conductivity may be the most important component in limiting the plant water use.

Plants that have high photosynthetic carbon assimilation generally present higher water losses through transpiration and, generally, great consumption of water that implies in the productivity increment. In this current study, the results demonstrate that, although the net photosynthetic rates of the clone were inferior to the ones presented by the seedlings, the TC3 and TC9 clones were similar to the seedlings for leaf area, stem diameter, root length, root volume, root dry mass and root surface area (Table 2). According to the data presented in Table 2, no difference was observed between the genetic materials (TC3, TC9, TC15 and seedling) when considering the variables of shoot growth, dry mass of root, average diameter of the roots and volume of the thin roots $(\varnothing 0-2 \mathrm{~mm})$.

In the current study with Toona ciliata, it was observed reduced ratio (RSA/RDM) in the seedlings, but did not influence the kroot, since there was no difference between the genetic material (Table 2 and Figure 2). In rootstocks of peaches with reduced surface area of thin roots per unit of root dry mass (RSA/RDM), Solari, Pernice and Dejong (2006) verified lower kroot when compared to the more vigorous rootstock.

On the other hand, Rieger and Litvin (1999) studied two woody species and three herbaceous species which exhibit a range of root anatomical features: Asparagus densiflorus (Kunth) Jessop (asparagus), Dendrobium superbum Rchb. F (Dendrobium), Glycine max (L.) Merr. (Soybean), Prunus persica (L.) Batsch (Peach) and Citrus aurantium L. (sour orange). The hydraulic conductivity was inversely related to root diameter and cortex width suggesting that species with thinner roots or roots with a thin cortex had the highest root hydraulic conductivity. 
Table 2 - Height $(H)$, stem diameter (SD), leaves number $(\mathrm{LN})$, Leaf area $(\mathrm{LA})$, shoot dry mass (SDM), root dry mass (RDM), total root length (TRL) and length of thin root (LR Ø 0-2mm), average root diameter (RD), total volume (TV) and volume of thin $\operatorname{root}(\mathrm{VR} \emptyset 0-2 \mathrm{~mm})$, thin root surface area (RSA Ø 0-2mm), surface area and roots dry mass ratio (RSA/RDM) of three clones (TC3, TC9 e TC15) and seminiferous Toona ciliata clones at 120 days.

Tabela 2 - Altura da parte aérea $(\mathrm{H})$, diâmetro do colo (DAC), número de folhas (NF), área foliar (AF), massa seca da parte aérea (MSPA), massa seca (MSR), comprimento total (CRT) e até $2 \mathrm{~mm}$ de diâmetro (CR Ø 0-2 mm), diâmetro médio (DMR), volume total (VR) e até $2 \mathrm{~mm}$ de diâmetro (VR Ø 0-2 mm), área superficial de raiz (ASR) e até $2 \mathrm{~mm}$ de diâmetro (ASR Ø 0-2 mm) e relação área superficial por massa seca de raiz (ASR/MSR) de três clones (TC3, TC9 e TC15) e mudas seminíferas de Toona ciliata aos 120 dias.

\begin{tabular}{|c|c|c|c|c|c|c|c|c|c|c|}
\hline \multirow{3}{*}{$\begin{array}{l}\text { Variables } \\
\mathrm{H}(\mathrm{m})\end{array}$} & \multicolumn{10}{|c|}{ Genotypes } \\
\hline & \multicolumn{2}{|c|}{ TC3 Clone } & \multicolumn{2}{|c|}{ TC9 Clone } & \multicolumn{2}{|c|}{ TC15 Clone } & \multicolumn{2}{|c|}{ Seedlings } & \multirow{2}{*}{$\begin{array}{c}\text { Average } \\
0.146\end{array}$} & \multirow{2}{*}{$\begin{array}{l}\text { CV } \\
(\%)\end{array}$} \\
\hline & 0.111 & B & 0.108 & B & 0.136 & B & 0.220 & A & & \\
\hline $\mathrm{SD}(\mathrm{m})$ & 0.00600 & B & 0.00651 & $\mathrm{AB}$ & 0.0072 & A & 0.00601 & B & 0.0064 & 9.8 \\
\hline LN & 7.6 & B & 5.80 & B & 6.80 & B & 10.0 & A & 7.6 & 17.1 \\
\hline $\mathrm{LA}\left(\mathrm{m}^{2}\right)$ & 0.07102 & A & 0.06154 & A & 0.06852 & A & 0.06207 & A & 0.06579 & 17.6 \\
\hline SDM (g) & 5.11 & $\mathrm{AB}$ & 5.0 & $\mathrm{AB}$ & 5.83 & A & 4.21 & B & 5.04 & 11.3 \\
\hline RDM (g) & 1.83 & A & 1.96 & A & 2.37 & A & 2.18 & A & 2.09 & 20.6 \\
\hline TRL (m) & 22.64 & B & 24.77 & $A B$ & 29.25 & A & 22.21 & B & 24.72 & 14.0 \\
\hline $\begin{array}{l}\mathrm{LR}(\mathrm{m}) \\
\varnothing 0-2 \mathrm{~mm}\end{array}$ & 22.192 & B & 24.073 & $A B$ & 28.640 & A & 21.856 & B & 24.190 & 13.8 \\
\hline $\mathrm{RD}(\mathrm{m})$ & 0.000613 & A & 0.000625 & A & 0.000632 & A & 0.000620 & A & 0.000622 & 4.7 \\
\hline $\mathrm{TV}\left(\mathrm{m}^{3}\right)$ & 0.0000072 & $\mathrm{AB}$ & 0.0000088 & $A B$ & 0.0000095 & A & 0.0000067 & B & 0.0000081 & 18.2 \\
\hline $\begin{array}{l}\mathrm{VR}\left(\mathrm{m}^{3}\right) \\
\varnothing 0-2 \mathrm{~mm}\end{array}$ & 0.0000066 & A & 0.0000078 & A & 0.0000085 & A & 0.0000062 & A & 0.0000073 & 17.6 \\
\hline $\operatorname{RSA}\left(\mathrm{m}^{2}\right)$ & 0.04527 & $\mathrm{AB}$ & 0.05245 & $A B$ & 0.05896 & A & 0.04332 & B & 0.05000 & 15.8 \\
\hline $\begin{array}{l}\text { RSA }\left(\mathrm{m}^{2}\right) \\
\varnothing 0-2 \mathrm{~mm}\end{array}$ & 0.03622 & $\mathrm{AB}$ & 0.04064 & $A B$ & 0.04658 & A & 0.03459 & B & 0.03951 & 15.5 \\
\hline $\begin{array}{l}\text { RSA/ } \\
\text { RDM }\end{array}$ & 25.27 & A & 26.65 & A & 25.08 & A & 20.06 & B & 24.27 & 9.5 \\
\hline
\end{tabular}

Fonte: Oliveira, T. P. F. (2016)

The difference between the architecture/anatomy of the root system of the seedlings may have contributed to the results in the present study. The tendency of the clones is to present a root system with more root volume, root hair and surface area, when compared to seedlings. The seedlings present higher amount of thick and lignified roots. Anatomically, an adventitious root may have anatomical differences from a primary root formed by the seedlings, which can affect root hydraulic conductivity and consequently gas exchange, growth, and productivity. Jesus et al. (2010) verified that there is an anatomical difference between adventitious roots and primary root for the Coffea arabica Rubi cultivar. The adventitious roots presented larger diameter of the vascular cylinder in relation to the primary root of the seedlings. These authors report that there may be an increase in the hydraulic conductivity of these adventitious roots, assuming the root hydraulic conductivity is directly related to the diameter of the vascular cylinder. 
The results of the gas exchange shown in Table 1 corroborate the data presented in Table 3 , in which a significant and positive correlation between net photosynthetic rate $(A)$ and stomatal conductance, and between $A$ and $E$, are shown (Table 3 ). There was a negative correlation between $k_{\text {root }}$ and root dry mass (RDM), (Table 3). This result showed that more biomass production reduced $k_{\text {root }}$ in 120 days after planting. We can hypothesize that the root system confinement in Toona ciliata clones and seedlings promoted root deformation, reducing $k_{\text {root. }}$ Actually, root confinement in pots could negatively impact the formation of new roots, since there is limited physical space for the growth of fine roots, which are responsible for the higher uptake of water and mineral nutrients (RICHARDS; ROWE, 1977). This reduction in the physical space can result in the reduction in the $k_{\text {root }}$, since the quantity of thick and more suberized roots would be bigger and could contribute to the elevation of the root dry mass and root volume. Possibly, if the plants of the current study remained for less time in the greenhouse, the root restriction would be minimized and an increment in the hydraulic conductivity of the roots could be observed.

Another indicative that these plants may be under a root confinement are the negative correlations between the gas exchange and the root growth. However, in the current study, these correlations were negative and were not significant (Table 3). The studies developed by Ronchi et al. (2006) and Shi et al. (2008) have demonstrated that there was a reduction in the net photosynthetic rate when the root restriction in seedlings of Coffea arabica and Lycopersicon esculentum increased, due to stomatal or non-stomatal effects. Ronchi et al. (2006) reported that the severe reduction of photosynthesis in those seedlings grown under root restriction occurred due to the non-stomatal factors, such as decreased Rubisco activity. Shi et al. (2008) verified that the reduction of $\mathrm{CO}_{2}$ assimilation rates was largely due stomatal limitation. Reduced values in leaf water potential, stomatal conductance, transpiration, intracellular $\mathrm{CO}_{2}$ concentration and increased stomatal limitation and the xylem sap ABA concentration were also found in these seedlings.

Figueiredo et al. (2014b) evaluated the influence of the permanency time of the three eucalyptus clones under no coverage, at the nursery (clear sky), on the net photosynthetic rate and observed that the longest time of permanency (180 days) of the clones in pots of $53 \mathrm{~cm}^{3}$ resulted in reductions in the net photosynthetic capacity, evidencing that in these conditions the clones were affected with the mechanical root restrictions.

There were significant positive correlations between stem diameter with total root length (TRL), root volume (RV), and root surface area (RSA). There were also positive correlations between the root dry mass (DMR) and the volume, the surface area of total roots, and the volume expressed in roots smaller than $2 \mathrm{~mm}$. The DMR was also positively correlated to the length of the roots. In addition, there were positive correlations with A versus gs and A versus $\mathrm{E}$ (Table 3). The genotypes that exhibited higher iWUE were the TC9 and TC15 clones. The seedlings exhibited a lower iWUE and WUE $\left(A / g s-77.7 \mu \mathrm{mol} \mathrm{CO}_{2} \mathrm{~mol} \mathrm{H}_{2} \mathrm{O}^{-1} ; A / E-2.18 \mu \mathrm{mol} \mathrm{CO}_{2} \mathrm{mmol}\right.$ $\left.\mathrm{H}_{2} \mathrm{O}^{-1}\right)$, although it did not differ from the TC3 clone $\left(A / E-2.57 \mu \mathrm{mol} \mathrm{CO} \mathrm{mmol} \mathrm{H}_{2} \mathrm{O}^{-1} ; \mathrm{A} / g \mathrm{~s}-\right.$ $101.8 \mu \mathrm{mol} \mathrm{CO}_{2} \mathrm{~mol} \mathrm{H}_{2} \mathrm{O}^{-1}$ ) (Table 4). The iWUE and WUE of clone TC9 were $55 \%$ and $27 \%$ higher than the seedlings (Table 4).

Although seedlings exhibited elevated net photosynthetic rate, they showed reduced iWUE $(A / g s)$ and WUE $(A / E)$. This result contrasted with the TC9 clone which, besides the reduced value of $A$ and $E$, presented a higher iWUE among the genetic materials studied (Table 1 and 4). As $g_{s}$ was very reduced in the seedlings of the TC9 clone, this reduction suggests these seedlings were submitted to reduced tensions of the xylem in relation to the other genotypes.

According to El-Sharkawy, Cock and Hernandez (1985), the reduction in the stomatal conductance can reduce the water loss of the leaves, causing an increase in the water use efficiency. Results obtained by Rocha and Moraes (1997) using young plants of Stryphondendron adstringens corroborate this current study with Toona ciliata seedlings, in which the increase in the water use efficiency occurred in the genotypes with lower values of stomatal conductance 
and transpiration. The authors demonstrate that Stryphondendron adstringens is well adapted to the conditions of water limitation in the soil.

Table 3 - Pearson's correlation between the variables: root hydraulic conductivity, stem diameter (SD), leaf area (LA), root dry mass (RDM), root diameter $(R D)$, diameter

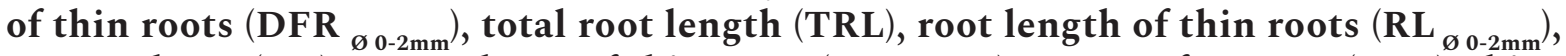
root volume $(R V)$, root volume of thin roots $\left(R V_{\varnothing 0-2 \mathrm{~mm}}\right)$, root surface area $(R S A)$, thin root surface area $\left(\mathrm{RSA}_{\varnothing 0-2 \mathrm{~mm}}\right)$, net photosynthetic rate $(\mathrm{A})$; stomatal conductance $\left(\mathrm{g}_{\mathrm{s}}\right)$; transpiration $(\mathrm{E})$ of Toona ciliata seedlings and clones.

Tabela 3 - Correlação de Pearson entre as variáveis, condutividade hidráulica das raízes $\left(K_{\text {raiz }}\right)$ em quatro pressões $(0,1 ; 0,2 ; 0,3$ e $0,4 \mathrm{MPa})$, diâmetro do colo (DAC), área foliar (AF), massa seca das raízes (MSR), diâmetro médio das raízes (DMR), diâmetro médio das raízes até $2 \mathrm{~mm}$ de diâmetro ( $\mathrm{DMR} \varnothing 0-2 \mathrm{~mm}$ ), comprimento das raízes (CR), comprimento de raízes

até $2 \mathrm{~mm}$ de diâmetro $(\mathrm{CR} \varnothing 0-2 \mathrm{~mm})$, volume das raízes $(\mathrm{V})$, volume das raízes finas $(\mathrm{V} \varnothing$ $0-2 \mathrm{~mm}$ ), área superficial das raízes (ASR), área superficial de raízes finas (ASR $\varnothing 0-2 \mathrm{~mm}$ ), fotossíntese $(A)$; condutância $(g s)$; transpiração $(E)$ de mudas seminíferas e clonais de Toona ciliata.

\begin{tabular}{|c|c|c|c|c|c|c|c|c|c|c|c|c|c|c|c|}
\hline$j \cdot \frac{\pi}{\partial}$ & $\mathbf{k}_{\text {root }}$ & SD & LA & RDM & RD & $\begin{array}{l}\text { DMR } \\
\varnothing 0-2 m m\end{array}$ & TRL & $\begin{array}{l}\mathrm{RL}_{\varnothing} \\
0-2 \mathrm{~mm}\end{array}$ & $\mathbf{R V}$ & $\begin{array}{l}\mathbf{R V _ { \varnothing }} \\
0-2 \mathrm{~mm}\end{array}$ & RSA & $\begin{array}{c}\text { RSA } \\
\varnothing \\
0-2 \mathrm{~mm} \\
\end{array}$ & A & $\mathbf{g}_{\mathrm{s}}$ & E \\
\hline $\mathrm{k}_{\text {root }}$ & 1 & & & & & & & & & & & & & & \\
\hline SD & 0,16 & 1 & & & & & & & & & & & & & \\
\hline LA & $-0,03$ & $-0,23$ & 1 & & & & & & & & & & & & \\
\hline RDM & $-0,25^{*}$ & 0,3 & $-0,07$ & 1 & & & & & & & & & & & \\
\hline $\mathrm{RD}$ & $-0,04$ & 0,33 & $-0,01$ & 0,25 & 1 & & & & & & & & & & \\
\hline $\begin{array}{l}\text { DMR } \\
\varnothing \\
0-2 \mathrm{~mm}\end{array}$ & $-0,12$ & 0,25 & 0,13 & 0,13 & $0,93^{*}$ & 1 & & & & & & & & & \\
\hline TRL & $-0,24$ & $0,44^{*}$ & 0,06 & $0,78^{*}$ & 0,37 & 0,29 & 1 & & & & & & & & \\
\hline $\begin{array}{l}\mathrm{RL} \\
\varnothing \\
0-2 \mathrm{~mm}\end{array}$ & $-0,24$ & 0,44 & 0,06 & $0,79^{*}$ & 0,35 & 0,28 & $0,99^{*}$ & 1 & & & & & & & \\
\hline $\mathrm{RV}$ & $-0,21$ & $0,46^{*}$ & 0,04 & $0,68^{*}$ & $0,74^{*}$ & $0,65^{*}$ & $0,88^{*}$ & $0,87^{*}$ & 1 & & & & & & \\
\hline $\begin{array}{l}\text { RV } \\
\varnothing \\
0-2 \mathrm{~mm}\end{array}$ & $-0,29$ & 0,42 & 0,14 & $0,68^{*}$ & $0,66^{*}$ & $0,63^{*}$ & $0,90^{*}$ & $0,90^{*}$ & $0,96^{*}$ & 1 & & & & & \\
\hline RSA & $-0,23$ & $0,47^{\star}$ & 0,05 & $0,73^{*}$ & $0,58^{*}$ & $0,50^{*}$ & $0,66^{*}$ & $0,67^{\star}$ & $0,97^{*}$ & $0,97^{*}$ & 1 & & & & \\
\hline $\begin{array}{l}\text { RSA } \\
\varnothing \\
0-2 \mathrm{~mm}\end{array}$ & $-0,25$ & $0,46^{*}$ & 0,1 & $0,73^{*}$ & $0,55^{*}$ & $0,50^{*}$ & $0,69^{*}$ & $0,70^{*}$ & $0,95^{*}$ & $0,97^{\star}$ & $0,99^{*}$ & 1 & & & \\
\hline$A$ & 0,03 & 0,01 & $-0,29$ & 0,14 & $-0,25$ & $-0,17$ & $-0,13$ & $-0,11$ & $-0,24$ & $-0,16$ & $-0,19$ & $-0,16$ & 1 & & \\
\hline$g_{s}$ & 0 & $-0,13$ & $-0,37$ & $-0,03$ & $-0,3$ & $-0,22$ & $-0,33$ & $-0,32$ & $-0,4$ & $-0,33$ & $-0,36$ & $-0,34$ & $0,96^{*}$ & 1 & \\
\hline$E$ & 0,02 & $-0,09$ & $-0,3$ & 0,12 & $-0,31$ & $-0,24$ & $-0,21$ & $-0,19$ & $-0,32$ & $-0,24$ & $-0,28$ & $-0,24$ & $0,99^{*}$ & $0,98^{*}$ & 1 \\
\hline
\end{tabular}


Table 4 - Intrinsic water use efficiency $\left(\mu_{\text {molCO}} \mathrm{mol} \mathrm{H}_{2} \mathrm{O}^{-1}\right)$ and water use efficiency $\left(\mu \mathrm{molCO}_{2} \mathrm{mmol} \mathrm{H}_{2} \mathrm{O}^{-1}\right.$ ) of three clones (TC3, TC9 e TC15) and seedlings Toona ciliata clones at 120 days.

Tabela 4 - Eficiência intrínseca e instantânea do uso da água de três clones (TC3, TC9 e TC15) e de mudas propagadas por sementes de Toona ciliata aos 120 dias.

\begin{tabular}{|c|c|c|c|c|c|c|c|c|c|c|}
\hline \multirow[b]{2}{*}{ Variables } & \multicolumn{10}{|c|}{ Genotypes } \\
\hline & \multicolumn{2}{|c|}{$\begin{array}{c}\text { TC3 } \\
\text { Clone }\end{array}$} & \multicolumn{2}{|c|}{$\begin{array}{l}\text { TC9 } \\
\text { Clone }\end{array}$} & \multicolumn{2}{|c|}{$\begin{array}{l}\text { TC15 } \\
\text { Clone }\end{array}$} & \multicolumn{2}{|c|}{ Seedlings } & Average & CV $(\%$ \\
\hline $\begin{array}{l}\text { efficiency } \\
\left(\mu \mathrm{molCO}_{2} \mathrm{molH}_{2} \mathrm{O}^{-1}\right)\end{array}$ & 101.8 & $\mathrm{C}$ & 172.5 & A & 130.1 & B & 77.7 & $\mathrm{C}$ & 120.5 & 12.3 \\
\hline $\begin{array}{l}\text { Water use efficiency } \\
\left(\mu \mathrm{molCO}_{2} \mathrm{mmolH}_{2} \mathrm{O}^{-1}\right)\end{array}$ & 2.6 & $A B$ & 3.0 & A & 2.7 & A & 2.2 & B & 2.6 & 10.1 \\
\hline
\end{tabular}

Averages followed by the same capital letter in the line do not differ among themselves by Tukey's test $\mathrm{P}<0.05$.

The difference found between the genetic materials in the present study can use as a basis for future studies of Toona ciliata genotype selection. Among the clone studied, the TC3 showed to be a promising clone in the aspects related to the water conservation in shoot, since this clone has a higher $k_{\text {root }}$ and an efficient control of the water loss through the leaves. However, new studies need to be done in order to obtain more conclusive information. The results can show a special attention to obtain more research related to possible relations between the root hydraulic conductivity and root restriction in genotypes of Toona ciliata, as well as further studies needed to verify the behavior of the clones studied when considering water deficit.

\section{Conclusion}

The genetic materials studied exhibited an equal capacity of water absorption and transport by the roots, even though they exhibited visual anatomical differences of the root system. Although the clones presented low transpiration and net photosynthetic rate they were generally more efficient in water use, and the TC3 and TC9 clones were more efficient to convert the assimilated carbon to biomass.

\section{Acknowledgement}

We thank 'Fundação de Amparo à Pesquisa do Estado do Rio de Janeiro' (FAPERJ) for the financial support. The authors thank The National Council for Scientific and Technological Development (CNPq, Brazil) for the fellowships awarded to E. Campostrini.

\section{References}

ATKIN, O. K.; SCHEURWATER, I.; PONS, T. L. Respiration as a percentage of daily photosynthesis in whole plants is homeostatic at moderate, but not high, growth temperatures. New Phytologist, Lancaster, v. 174, n. 2, p. 367-380, 2007. 
BOURSIAC, Y. et al. The response of Arabidopsis root water transport to a challenging environment implicates reactive oxygen species-and phosphorylation-dependent internalization of aquaporins. Plant Signaling \& Behavior, Londres, v. 3, n. 12, p. 1096-1098, dec. 2008.

BOYER, J. S. Water transport. Annual Review of Plant Physiology, Palo Alto, v. 36, p. 473-516, jun. 1985.

EL-SHARKAWY, M. A.; COCK, J. H.; HERNANDEZ, A. D. P. Stomatal response to air humidity and its relation to stomatal density in a wide range of warm climate species. Photosynthesis Research, [S.1.], v. 7, n. 2, p. 137-149, jan. 1985.

FIGUEIREDO, F. A. M. M. A. et al. Condutividade hidráulica de raiz e capacidade fotossintética de mudas clonais de eucalipto com indução de deformações radiculares. Ciência Florestal, Santa Maria, v. 24, n. 2, p. 1-10, abr./jun. 2014a.

FIGUEIREDO, F. A. M. M. A. et al. Trocas gasosas, relações hídricas e eficiência fotoquímica em mudas clonais de eucalipto com permanência prolongada em tubetes. Scientia Forestalis, Piracicaba, v. 42, n. 104, p. 533-542, dec. 2014b.

FITTER, A. H. Characteristics and functions of root systms. In: WAISEL, Y.; ESHEL, A.; KAFI, U. (Ed.). Plant Roots: the hidden half. New York: Marcel Dekker, 1991. p. 3-24.

GILBERT, M. E. et al. Field confirmation of genetic variation in soybean transpiration response to vapor pressure deficit and photosynthetic compensation. Field Crops Research, Brisbane, v. 124, n. 1, p. 85-92, oct. 2011.

GONÇALVES, J. L. M.; MELLO, S. L. M. O sistema radicular das árvores. In: GONÇALVES, J. L. M.; BENEDETTI, V. (Ed.). Nutrição e fertilização de florestas. Piracicaba: IPEF, 2005. p. 221-267.

GHOLIPOOR, M. et al. Genetic variability of transpiration response to vapor pressure deficit among sorghum genotypes. Field Crops Research, Brisbane, v. 119, n. 1, p. 85-90, oct. 2010.

GREGORY, P. J. Root growth and activity. In: BOOTE, K. J. et al. Phisiology and determination of crop yield, Florida: University of Florida, 1994. p. 65-93.

HUBBARD, R. M.; BOND, B. J.; RYAN, M. G. Evidence that hydraulic conductance limits photosynthesis in old Pinus ponderosa trees. Tree Physiology, Victoria, v. 19, n. 3, p. 165-172, mar. 1999.

JESUS, A. M. S. et al. Observações anatômicas em plantas de Coffea arabica L. obtidas por enraizamento de estacas. Revista Ceres, Viçosa, MG, v. 57, n. 2, p. 175-180, mar./abr. 2010.

JONES, H. G. Plants and microclimate: a quantitative approach to environmental plant physiology. 2th ed. Cambridge: Cambridge University Press, 1992.85 p.

KHOLOVA, J. et al. Constitutive water conserving mechanisms are correlated with the terminal drought tolerance of pearl millet [Pennisetum glaucum (L.) R. Br.]. Journal of Experimental Botany, Lancaster, v. 61, n. 2, p. 367-377. Oct. 2010.

KNIPFER, T.; STEUDLE, E. Root hydraulic conductivity measured by pressure clamp is substantially affected by internal unstirred layers. Journal of Experimental Botany, Lancaster, v. 59, n. 8, p. 2071-2084, apr. 2008.

KNIPFER, T.; FRICKE, W. Water uptake by seminal and adventitious roots in relation to wholeplant water flow in barley (Hordeum vulgare L.). Journal of Experimental Botany, Lancaster, v. 62, n. 2, p.717-733, oct. 2011.

KOZLOWSKI, T. T.; PALLARDY, S. G. Physiology of woody plants. 2th ed. San Diego: Academic Press, 1997. 411 p.

MAUREL, C.; SIMONNEAU, T.; SUTKA, M. The significance of roots as hydraulic rheostats. 
Journal of Experimental Botany, Lancaster, v. 61, n. 12, p. 3191-3198, jun. 2010.

MURPHY, M. R. C.; JORDAN, G. J.; BRODRIBB, T. J. Differential leaf expansion can enable hydraulic acclimation to sun and shade. Plant, Cell and Environment, [S.l.], v. 35, p. 1407-1418, 2012.

PINHEIRO, A. L.; LANI, L. L.; COUTO, L. Cedro Australiano: cultivo e utilização (Toona ciliata M.Roem. var. australis (F. Muell) Bahadur. Viçosa, MG: UFV, 2006. 42 p.

RAVEN, P. H.; EICHHOM, S. E.; EVERT, R. F. Biologia vegetal. 8. ed. Rio de Janeiro: Guanabara Koogan, 2014. 876 p.

RICHARDS, D.; ROWE, R. N. Effects of root restriction, root pruning and 6-benzylaminopurine on the growth of peach seedlings. Annals of Botany, Exeter, v. 41, n. 4, p. 729-740, jul. 1977.

RIEGER, M.; LIVTIN, P. Root system hydraulic conductivity in species with contrasting root anatomy. Journal of Experimental Botany, Lancaster, v. 50, n. 331, p. 201-209, feb. 1999.

ROCHA, A. M. S.; MORAES, J. A. P. V. Influência do estresse hídrico sobre as trocas gasosas em plantas jovens envasadas de Stryphnodendron adstringens (Mart.) Coville. Revista Brasileira de Fisiologia Vegetal, Campinas, v. 9, n. 1, p. 41-46, 1997.

RONCHI, C. P. et al. Growth and photosynthetic down-regulation in Coffea arabica in response to restricted root volume. Functional Plant Biology, Melbourne, v. 33, n. 11, p. 1013-1023, jan. 2006.

SHI, K. et al. Root restriction-induced limitation to photosynthesis in tomato (Lycopersicon esculentum Mill.) leaves. Scientia Horticulturae, Amsterdam, v. 117, n. 3, p. 197-202, jul. 2008.

SINCLAIR, T. R.; ZWIENIECKI, M. A.; HOLBROOK, N. M. Low leaf hydraulic conductance associated with drought tolerance in soybean. Physiologia Plantarum, Lund, v. 132, n. 4, p. 446451, apr. 2008.

SOLARI, L. I.; PERNICE, F.; DEJONG, T. M. The relationship of hydraulic conductance to root system characteristics of peach (Prunus persica) rootstocks. Physiologia Plantarum, Lund, v. 128, n. 2, p. 324-333, oct. 2006.

STEUDLE, E.; PETERSON, C. A. How does water get through roots? Journal of Experimental Botany, Lancaster, v. 49, n. 322, p. 775-788, may 1998.

TOMBESI, S. et al. Relationships between xylem vessel characteristics, calculated axial hydraulic conductance and size controlling capacity of peach rootstocks. Annals of Botany, Exeter, v. 105, n. 2, p. 327-331, nov. 2010.

TYREE, M. T. Hydraulic properties of roots. In: KROON, H.; VISSER, E. J. W. (Ed.). Root ecology. Berlin: Springer, 2003. p. 125-150.

TYREE, M. T.; EWERS, F. W. The hydraulic architecture of trees and other woody-plants. New Phytologist, Lancaster, v. 119, n. 3, p. 345-360, apr. 1991. 